International Journal of Current Microbiology and Applied Sciences

ISSN: 2319-7706 Volume 6 Number 3 (2017) pp. $482-489$

Journal homepage: http://www.ijcmas.com

Original Research Article

https://doi.org/10.20546/ijcmas.2017.603.056

\title{
Comparative Efficacy of Different Methods of Application of Trichoderma harazianum Rifai. in the Management of Dry Root Rot of Chilli (Capsicum annum) Caused by Rhizoctonia solani (kuhn)
}

\author{
Aniruddh Prasad Pandey, Sunil Zacharia and Nithin B. Patil*
}

Department of Plant Protection, Sam Higginbottom Institute of Agriculture, Technology and Sciences, Allahabad, Uttar Pradesh, India

*Corresponding author

\section{A B S T R A C T}

K e y w o r d s
Trichoderma
harzianum,
Rhizoctonia solani,
Capsicum annum,
Dry root rot.

\begin{abstract}
In the present study, all the three selected varieties of chilli viz. G-4, NP-46 and Faridabad were susceptible to dry root-rot caused by Rhizoctonia solani. The different modes of application of Trichoderma harzianum were found effective to manage the dry root rot but most effective was found with dry seed treatment. The population density (cfu) of Rhizoctonia solani increased till 30 days after sowing (DAS) then it was stagnant and decreased up to 60 DAS while in case of Trichoderma harzianum the cfu increased up to 30 DAS and then gradually decreased up to 45 DAS and remained stagnant up to 60 DAS. The dry root rot was managed by Trichoderma harzianum to maximum extent up to 30 DAS after which the disease incidence increased, which may be ascribed to variations in the rhizosphere which may had adverse impact on further colonization by Trichoderma harzianum but however, it showed effectiveness up to 30 DAS.
\end{abstract}

\section{Introduction}

India is the second largest producer of the vegetables in the world. India produced 146.55 million tonnes of vegetables from 8.49 $\mathrm{m}$ ha of land with productivity of 17.26 tonnes/ ha (Indian Horticulture Database, 2011). Chilli is cultivated throughout the country. Chilli is cultivated in about 0.782 million ha with annual production of 1.223 million tonnes in India (Indian Horticulture Database, 2011). In recent years production of chilli has been declining mainly because different varieties of chilli are susceptible to many fungal and viral diseases. Among them, prominent are anthracnose and ripe rot caused by Colletotricum spp., damping off and dry root rot by Rhizoctonia spp., damping off by Pythium spp., leaf curl by viruses etc. Rhizoctonia solani is one of the most destructive plant pathogens over the world and is capable of attacking a tremendous range of host plants causing seed decay, root rot, pre and post emergence damping off of the vegetables, cereals, fruits, ornamentals, and oil seed crops. Being pathogen of great diversity with wide host range and lack of sharp differentiation among its specialized strains Rhizoctonia solani poses great challenge to plant pathologists for its management. Biological control is regarded as an eco-friendly and non-poisonous which 
does not lead to any hazardous effects on plants or human being. Bio-control is the reduction in the amount of inoculum or disease producing activity of pathogen accomplished by or through one or more organisms other than inoculum. Trichoderma harzianum Rifai has greater rhizosphere competence and parasitizes the pathogenic fungi. These grow tropically towards the target pathogen hyphae (Chet et al., 1979; Durral, 1968). There have been many reports of successful use of antagonistic fungi in controlling soil borne pathogenic fungi (Harman et al., 1981). The different species of Trichoderma are known to be antagonist to Rhizoctonia solani causing different diseases on various host range and successively manage the different diseases (Mathur et al., 2002; Saxena and Saxena, 2002; Sharma and Gupta, 2003).

\section{Materials and Methods}

\section{Isolation and identification of pathogen Rhizoctonia solani}

The suspected pathogen used in the experiment was isolated from the root and collar region of infected chilli plants showing characteristics symptoms. The infected roots were uprooted, washed and before culturing, infected parts were viewed under stereoscopic binocular microscope for examining ascertaining and the pathogen. Small pieces of infected plant parts were surface sterilized with $\mathrm{HgCl}_{2} \quad(0.1 \%)$ and washed in three changes of sterilized distilled water and kept over the solidified PDA medium inside Petri dishes aseptically. These Petri-plates were then incubated at $25 \pm 2^{\circ} \mathrm{C}$. On $3^{\text {rd }}$ day a creamish growth was observed. From this colony, a portion from the periphery was taken and transferred to other Petri dishes having medium to get pure culture which was achieved by hyphal-tip method. The pathogen was identified as Rhizoctonia solani by its cultural characteristics, microscopic studies and referring the relevant monographs and literature. The Koch's postulates were tested to confirm the pathogenicity of the fungus.

\section{Isolation and identification of bio-control agent Trichoderma harzianum}

The healthy chilli plants were brought to the laboratory by gently uprooting them without disturbing the root system in paper bag. The soil adhering to the root system was removed with the help of brush and by gentle tapping. One gram of such soil was suspended in $9 \mathrm{ml}$ of sterilized distilled water and shaken thoroughly. One $\mathrm{ml}$ suspension was transferred from this to $9 \mathrm{ml}$ of sterile water in a test tube to get 1: 10 dilutions. Serial dilutions were made by transferring one $\mathrm{ml}$ of suspension to subsequent tubes to get dilution of $1 \times 10^{-4}$. One $\mathrm{ml}$ of the desired soil suspension was transferred to six sterilized Petri dishes and then poured with potato dextrose agar (PDA) and incubated at $25 \pm 2^{\circ} \mathrm{C}$ for 3-4 days. The identification of Trichoderma harzianum was done by comparing the morphological and cultural characteristics described in the relevant literature (Rifai, 1969). Later it was purified and sub-cultured on potato dextrose agar slants with labels.

\section{In vitro evaluation of Trichoderma} harzianum against Rhizoctonia solani

To test the antagonistic ability of Trichoderma harzianum, dual culture technique (Marton and Stroybeg, 1955) was adopted. Culture discs $(5 \mathrm{~mm})$ each of the fungal antagonist and the pathogen were taken from the margin of the actively growing cultures and transferred to petri plates containing PDA medium on opposite sides approximately at one $\mathrm{cm}$ away from the wall of the plate. A control having the test pathogen only was also kept for comparison. 
The Petri-plates were subsequently incubated at $25 \pm 1^{0} \mathrm{C}$ till the control plate was completely covered by Rhizoctonia solani colonies. Each treatment was replicated thrice. Colony diameter of the test fungus as well as the antagonist up to the zone of inhibition was recorded and percent growth inhibition of the test pathogen over control was calculated using the following formula Antagonistic effect $=\{(\mathrm{A}-\mathrm{B}) / \mathrm{A}\} \times 100$

Where,

$\mathrm{A}=$ Diameter of mycelial growth of Rhizoctonia solani in control.

$\mathrm{B}=$ Diameter of mycelial growth of Rhizoctonia solani in treatment plates.

In vivo evaluation of Trichoderma harzianum against Rhizoctonia solani

In vivo evaluation was done in pot experiments under glass house conditions. Trial was taken in glass house of Department of Plant Protection, SHIATS. The experiment was laid in $3 \mathrm{X} 4$ factorial RBD with six replications. Three varieties of chilli viz., G-4, NP46, Faridabad were sown with treatments. Treatments were, $\mathrm{T}_{1}=$ Dry seed treatment, $\mathrm{T}_{2}=$ Slurry seed treatment, $\mathrm{T}_{3}=$ Soil drenching, $\mathrm{T}_{0}=$ Normal seeds without any treatment, for all three varieties. Treated seeds and control were sown in pot containing sterilized soil with Rhizoctonia solani inoculum. Observations were recorded on population density of pathogen and antagonists during a period of time.

\section{Results and Discussion}

\section{In vitro efficacy of Trichoderma harzianum against Rhizoctonia solani}

Dual culture technique was adopted for assessing the inhibition of growth of Rhizoctonia solani. The percent inhibition in growth of Rhizoctonia solani by Trichoderma harzianum was $38.14 \%$ over the control. The inhibitory effect of Trichoderma harzianum against Rhizoctonia solani was probably due to competition and/ or antibiosis.

\section{In vivo efficacy of Trichoderma harzianum against Rhizoctonia solani}

\section{Population density of Rhizoctonia solani in the rhizosphere}

Observations recorded on 15 days after sowing (DAS) (Table 1) revealed that colony forming units (cfu) of pathogen were maximum in the control (7.08) and minimum in dry seed treatment (2.47); however dry seed treatment was significantly superior to both the slurry seed treatment and soil drenching. Among varieties maximum cfu was on NP-46 and Faridabad (4.14) but statistically all were non-significant from one another. Among variety $\mathrm{x}$ treatment maximum cfu was in control of G-4 (7.16) and minimum was in dry seed treatment of G4 (2.33), however all treatment combinations were statistically non-significant. On 30 DAS, maximum cfu was found in variety Faridabad (4.93) and minimum was in G-4 (4.72) but all treatments were statistically non-significant. Among treatments least cfu was present in soil drenching (2.50) and maximum was in control (11.6); however all treatments were statistically non-significant from each other but were significant over the control in reducing the population density of Rhizoctonia solani. While in variety $\mathrm{x}$ treatment combinations, least cfu was in soil drenching of G-4 (2.41) and maximum was in dry seed treatment of Faridabad (2.83) but all the treatments were statistically nonsignificant from one another, but were significantly superior over the control in managing the dry root-rot disease. On 45 DAS, maximum cfu was in variety G-4 (4.33) and minimum was in NP-46 (4.27) but they were statistically non-significant from each 
other. Where as in treatment, maximum cfu was found in control (11.77) and all the treatments were found significantly superior over the control in managing the disease but statistically all the treatments were nonsignificant from one another. And in treatment $\mathrm{x}$ variety interaction, minimum cfu was counted in dry seed treatment of G-4 (1.50); however statistically all treatment combinations were non-significant from one another but significantly superior over the control. On 60 DAS, minimum cfu of pathogen was counted in variety Faridabad (4.12) and among treatments soil drenching (1.47). Treatments were found non-significant from one another but significantly superior over the control. Among variety $\mathrm{x}$ treatment combination, least was with soil drenching of G-4; however statistically all treatment combinations were non-significant from one another but significantly superior over the control in managing disease.

\section{Population density of Trichoderma harzianum in the rhizosphere}

Observations recorded on 15 DAS (Table 2) revealed that maximum cfu of antagonist was in variety NP-46 (3.52) and minimum was in G-4 (3.31) but all of them were nonsignificant statistically, while among treatments maximum cfu was counted in dry seed treatment (7.13); but both were statistically non-significant. Among combinations maximum was counted in dry seed treatment of NP-46 (7.33) and minimum was in soil drenching of G-4 (6.00); however all the treatment combinations were statistically non-significant from each other. On 30 DAS, maximum cfu was found in variety NP-46 (4.67) and minimum in G-4 (3.50), here variety G-4 was significantly inferior to the other two varieties. Among treatments maximum cfu was in dry seed treatment (7.2) and minimum in soil drenching (4.94), here soil drenching was significantly inferior to above both treatments. Whereas, among treatment combination maximum cfu was in dry seed treatment of G-4 (7.25) and minimum in soil drenching of Faridabad (4.83); however all were non-significant statistically. On 45 DAS, maximum cfu was in variety NP-46 (5.14) and minimum in Faridabad (4.68), here variety NP-46 was found superior to above two varieties, while among treatments maximum cfu was observed with dry seed treatment (7.4) and minimum with soil drenching (5.13) and statistically all treatments were significant from each other. Among variety $\mathrm{x}$ treatment combinations, maximum cfu was in dry seed treatment of $\mathrm{G}$ 4 (8.08) and minimum in soil drenching of G4 (5.08) but statistically all were nonsignificant from each other.

Table.1 Population density (cfu x 104/g soil) of Rhizoctonia solani in rhizosphere of different varieties of chilli in different treatments after 15, 30, 45, 60 DAS

\begin{tabular}{|c|c|c|c|c|c|c|c|c|c|c|c|c|c|c|c|c|c|c|c|c|}
\hline \multirow[b]{2}{*}{ Variety } & \multicolumn{4}{|c|}{ Control } & \multicolumn{4}{|c|}{ Dry seed treatment } & \multicolumn{4}{|c|}{$\begin{array}{l}\text { Slurry seed } \\
\text { treatment }\end{array}$} & \multicolumn{4}{|c|}{ Soil drenching } & \multicolumn{4}{|c|}{ Mean } \\
\hline & 15 & 30 & 45 & 60 & 15 & 30 & 45 & 60 & 15 & 30 & 45 & 60 & 15 & 30 & 45 & 60 & 15 & 30 & 45 & 60 \\
\hline G-4 & 7.16 & 11.5 & 11.8 & 11.2 & 2.33 & 2.50 & 1.50 & 1.75 & 3.33 & 2.50 & 2.16 & 1.66 & $\mathbf{3 . 5 0}$ & 2.41 & 1.83 & 1.33 & 4.08 & 4.72 & 4.33 & 3.97 \\
\hline NP-46 & 7.08 & 11.6 & 11.5 & 10.8 & 2.40 & 2.50 & 1.83 & 1.91 & 3.50 & 2.75 & 1.83 & 1.83 & 3.58 & 2.58 & 1.91 & 1.58 & 4.14 & 4.87 & 4.27 & 4.04 \\
\hline Faridabad & 7.00 & 11.8 & 12.0 & 11.5 & 2.66 & 2.83 & 1.50 & 1.66 & 3.25 & 2.58 & 1.75 & 1.83 & 3.66 & 2.50 & 2.00 & 1.50 & 4.14 & 4.93 & 4.31 & 4.12 \\
\hline Mean & 7.08 & 11.6 & 11.7 & 11.2 & 2.47 & 2.61 & 1.60 & 1.77 & 3.36 & 2.61 & 1.90 & 1.77 & 3.58 & 2.50 & 1.91 & 1.47 & & & & \\
\hline
\end{tabular}


Table.2 Population density (cfu x 104/g soil) of Trichoderma harzianum in rhizosphere of different varieties of chilli in different treatments after 15, 30, 45, 60 DAS

\begin{tabular}{|c|c|c|c|c|c|c|c|c|c|c|c|c|c|c|c|c|}
\hline \multirow[b]{2}{*}{ Variety } & \multicolumn{4}{|c|}{ Dry seed treatment } & \multicolumn{4}{|c|}{$\begin{array}{l}\text { Slurry seed } \\
\text { treatment }\end{array}$} & \multicolumn{4}{|c|}{ Soil drenching } & \multicolumn{4}{|c|}{ Mean } \\
\hline & 15 & 30 & 45 & 60 & 15 & 30 & 45 & 60 & 15 & 30 & 45 & 60 & 15 & 30 & 45 & 60 \\
\hline G-4 & 7.25 & 7.25 & 8.08 & 7.00 & 6.00 & 6.25 & 5.75 & 6.91 & $\mathbf{0}$ & 5.00 & 5.08 & 6.83 & 3.31 & 3.50 & 4.70 & 5.18 \\
\hline NP-46 & 7.33 & 7.25 & 7.83 & 7.08 & 6.75 & 6.83 & 7.66 & 6.91 & $\mathbf{0}$ & 4.83 & 5.08 & 6.83 & 3.52 & 4.67 & 5.14 & 4.85 \\
\hline Faridabad & 6.83 & 7.16 & 6.41 & 6.75 & 6.83 & 5.76 & 7.08 & 6.58 & $\mathbf{0}$ & 5.00 & 5.25 & 4.91 & 3.41 & 4.47 & 4.68 & 4.64 \\
\hline Mean & 7.13 & 7.20 & 7.40 & 6.94 & 6.50 & 6.22 & 6.83 & 6.80 & 0 & 4.94 & 5.13 & 5.72 & & & & \\
\hline
\end{tabular}

Table.3 Percent incidences of dry root- rot in different varieties of chilli in different treatments after $15,30,45,60$ DAS

\begin{tabular}{|c|c|c|c|c|c|c|c|c|c|c|c|c|c|c|c|c|c|c|c|c|}
\hline \multirow[b]{2}{*}{ Variety } & \multicolumn{4}{|c|}{ Control } & \multicolumn{4}{|c|}{ Dry seed treatment } & \multicolumn{4}{|c|}{$\begin{array}{l}\text { Slurry seed } \\
\text { treatment }\end{array}$} & \multicolumn{4}{|c|}{ Soil drenching } & \multicolumn{4}{|c|}{ Mean } \\
\hline & 15 & 30 & 45 & 60 & 15 & 30 & 45 & 60 & 15 & 30 & 45 & 60 & 15 & 30 & 45 & 60 & 15 & 30 & 45 & 60 \\
\hline G-4 & 42.0 & 53.5 & 63.1 & 67.3 & 6.83 & 6.16 & 11.3 & 12.4 & 15.2 & 6.30 & 11.4 & 12.4 & 25.7 & 12.9 & 22.8 & 25.7 & 22.4 & 19.7 & 27.2 & 30.2 \\
\hline NP-46 & 39.2 & 52.7 & 60.0 & 63.5 & 7.50 & 6.88 & 12.3 & 14.1 & 16.3 & 3.75 & 11.8 & 13.6 & 33.0 & 10.3 & 18.2 & 19.7 & 24.0 & 18.4 & 25.6 & 27.7 \\
\hline Faridabad & 38.2 & 23.5 & 63.7 & 66.2 & 8.60 & 7.05 & 12.1 & 13.8 & 16.8 & 8.73 & 14.5 & 16.5 & 40.8 & 16.7 & 21.4 & 21.5 & 26.1 & 21.5 & 27.9 & 29.5 \\
\hline Mean & 39.8 & 53.3 & 62.7 & 65.7 & 7.60 & 6.73 & 11.9 & 13.4 & 16.1 & 6.24 & 12.6 & 15.2 & 33.2 & 13.3 & 20.8 & 22.3 & & & & \\
\hline
\end{tabular}

Table.4 Variability parameters of different observations taken

\begin{tabular}{llllllll}
\hline Observations & SEm \pm & $\begin{array}{l}\text { F- ratio } \\
\text { (variety) }\end{array}$ & $\begin{array}{l}\text { CD } \\
(\mathbf{0 . 0 5})\end{array}$ & $\begin{array}{l}\text { F- ratio } \\
\text { (treatment) }\end{array}$ & $\begin{array}{l}\text { CD } \\
(\mathbf{0 . 0 5})\end{array}$ & $\begin{array}{l}\text { F- ratio } \\
\text { (interaction) }\end{array}$ & $\begin{array}{l}\text { CD } \\
(\mathbf{0 . 0 5})\end{array}$ \\
\hline $\begin{array}{l}\text { Population density of } \\
\text { Rhizoctonia solani }\end{array}$ & & & & & & & \\
\hline 15 DAS & $\mathbf{0 . 4 4}$ & $\mathbf{0 . 0 5}$ & $\mathbf{0 . 4 4}$ & $\mathbf{1 2 7 . 6 8}$ & $\mathbf{0 . 5 0}$ & $\mathbf{0 . 1 8}$ & $\mathbf{0 . 8 8}$ \\
\hline 30 DAS & $\mathbf{0 . 3 9}$ & $\mathbf{0 . 6 0}$ & $\mathbf{0 . 3 9}$ & $\mathbf{8 1 5 . 0 0}$ & $\mathbf{0 . 4 5}$ & $\mathbf{0 . 1 8 5}$ & $\mathbf{0 . 7 8}$ \\
\hline 45 DAS & $\mathbf{0 . 3 8}$ & $\mathbf{0 . 0 5 4}$ & $\mathbf{0 . 3 8}$ & $\mathbf{1 0 0 0 . 1 3}$ & $\mathbf{0 . 4 4}$ & $\mathbf{0 . 6 8}$ & $\mathbf{0 . 7 7}$ \\
\hline 60 DAS & $\mathbf{0 . 4 7 6}$ & $\mathbf{0 . 1 8}$ & $\mathbf{0 . 4 7}$ & $\mathbf{5 9 6 . 8 6}$ & $\mathbf{0 . 5 5}$ & $\mathbf{0 . 3 8}$ & $\mathbf{0 . 9 5}$ \\
\hline $\begin{array}{l}\text { Population density of } \\
\text { Trichoderma harzianum }\end{array}$ & & & & & & & \\
\hline 15 DAS & $\mathbf{1 . 7 2}$ & $\mathbf{0 . 0 2 9}$ & $\mathbf{1 . 7 3}$ & $\mathbf{3 1 . 5 8}$ & $\mathbf{1 . 9 9}$ & $\mathbf{0 . 0 5 3}$ & $\mathbf{3 . 4 5}$ \\
\hline 30 DAS & $\mathbf{0 . 4 3}$ & $\mathbf{0 . 4 9}$ & $\mathbf{0 . 4 3}$ & $\mathbf{3 3 3 . 0 0}$ & $\mathbf{0 . 4 9}$ & $\mathbf{0 . 6 3}$ & $\mathbf{0 . 8 6}$ \\
\hline 45 DAS & $\mathbf{0 . 4 1 9}$ & $\mathbf{2 . 9 2}$ & $\mathbf{0 . 4 1}$ & $\mathbf{3 9 0 . 0 0}$ & $\mathbf{0 . 4 8}$ & $\mathbf{5 . 7 9}$ & $\mathbf{0 . 8 3}$ \\
\hline 60 DAS & $\mathbf{0 . 4 1 5}$ & $\mathbf{4 . 5 4}$ & $\mathbf{0 . 4 1}$ & $\mathbf{3 7 7 . 3 3}$ & $\mathbf{0 . 4 8}$ & $\mathbf{2 . 5 7}$ & $\mathbf{0 . 8 3}$ \\
\hline Percent incidences of dry & & & & & & & \\
root- rot disease & & & & & & & \\
\hline 15 DAS & $\mathbf{2 . 9 3 8}$ & $\mathbf{3 . 1 4}$ & $\mathbf{2 . 7 4}$ & $\mathbf{1 5 3 . 5 8}$ & $\mathbf{3 . 3 9}$ & $\mathbf{3 . 7 2}$ & $\mathbf{5 . 8 8}$ \\
\hline 30 DAS & $\mathbf{4 . 3 2 7}$ & $\mathbf{1 . 0 2 5}$ & $\mathbf{4 . 3 3}$ & $\mathbf{1 6 2 . 0 3}$ & $\mathbf{5 . 0 0}$ & $\mathbf{0 . 2 6}$ & $\mathbf{8 . 6 7}$ \\
\hline 45 DAS & $\mathbf{3 . 6 0 5}$ & $\mathbf{0 . 8 7}$ & $\mathbf{3 . 6 1}$ & $\mathbf{2 6 4 . 4 3}$ & $\mathbf{4 . 1 7}$ & $\mathbf{0 . 3 6}$ & $\mathbf{7 . 2 2}$ \\
\hline 60 DAS & $\mathbf{3 . 1 2 9}$ & $\mathbf{1 . 3 3}$ & $\mathbf{3 . 1 3}$ & $\mathbf{3 7 3 . 0 0}$ & $\mathbf{3 . 6 2}$ & $\mathbf{0 . 6 5}$ & $\mathbf{6 . 2 7}$ \\
\hline
\end{tabular}


On 60 DAS, maximum cfu was counted in variety G-4 (5.18) and minimum in Faridabad (4.64), here population density of $T$. harzianum on the varieties G-4 and NP-46 were statistically significant over the variety Faridabad. Whereas, among treatments maximum was found in dry seed treatment (6.94) and minimum in soil drenching (5.72); however all the treatments were nonsignificant from one another. Among interaction maximum cfu was counted in dry seed treatment of NP-46 (7.08) and minimum in soil drenching of Faridabad (4.91); however all the treatment combinations were statistically non-significant from each other except soil drenching on Faridabad, which was statistically inferior to other treatment combinations (Table 4).

\section{Effect of Trichoderma harzianum on the incidence of dry root rot disease}

During the first observation at 15 DAS (Table 3), minimum incidence of disease was recorded in variety G-4 (22.4\%) and maximum was in Faridabad $(26.12 \%)$ and the variety G-4 was significantly superior over other two varieties. Among treatments, minimum was in dry seed treatment $(7.6 \%)$ and maximum was in control $(39.77 \%)$ and statistically all the treatments were significant from one another and were also significant over the control. Among treatment combinations, minimum disease incidence was with dry seed treatment of G-4 $(6.83 \%)$ and maximum in control of G-4 (42.66\%), however, all combinations were not significant with each other. During observation on 30 DAS, minimum incidence of disease was recorded in variety NP-46 $(18.45 \%)$ and maximum was in Faridabad $(21.83 \%)$ but they were all statistically nonsignificant from one another. And among treatments, minimum was in slurry seed treatment $(6.24 \%)$ and maximum was in control $(53.28 \%)$. Here, soil drenching was statistically inferior to other two methods but all were statistically significant over the control. Among treatment combination, minimum disease incidence was with slurry seed treatment of NP-46 (3.75\%) and maximum in control of G-4 (53.5\%). Observation on 45 DAS, minimum incidence of disease was recorded in variety NP-46 $(25.57 \%)$ and maximum was in Faridabad $(27.91 \%)$ but they all were statistically at par with one another. Among treatments, minimum was in dry seed treatment $(11.89 \%)$ and maximum was in control (62.26\%); however slurry seed treatment and dry seed treatment were found statistically at par but all three treatments were found significantly superior over the control. Among treatment combinations, minimum disease incidence was with dry seed treatment of G-4 (11.26\%) and maximum in control of Faridabad (63.73\%), however all combinations were statistically non-significant from each other but significant over control. Observation on 60 DAS, minimum incidence of disease was recorded in variety G-4 (27.71\%) and maximum was in NP-46 (30.16\%) but all were statistically non-significant from one another. Among treatments, minimum was in dry seed treatment $(13.41 \%)$ and maximum was in control (65.69\%). Treatments were however, statistically significant over control and the dry seed and slurry seed treatments were found at par statistically. Among treatment combinations, minimum disease incidence was with dry seed treatment of G-4 $(12.4 \%)$ and maximum in control of G-4 $(67.35 \%)$; however, all treatment combinations were found statistically nonsignificant from one another but they were significant over control of each variety. In this study, all the three varieties used viz. G-4, NP- 46 and Faridabad were found susceptible to dry root-rot. All the treatments used in the present experiments were found effective to varying extent but prominent was dry seed treatment with Trichoderma harzianum on 
different varieties of chilli. The studies on population density (cfu) of Rhizoctonia solani revealed that population increased till $30 \mathrm{DAS}$ then decreased up to 60 DAS while in case of Trichoderma harzianum the population increased up to 30 DAS and stagnant up to 60 DAS. The incidence of dry root-rot was recorded and found that the disease was managed by Trichoderma harzianum to maximum extent from 15 DAS to 30 DAS after which the disease increased. This may be due to the fact that population of Trichoderma harzianum also increased up to 30 DAS and thus managed the disease but after that there was not much appreciable increase in the population of Trichoderma harzianum which resulted on increase in the incidence of dry root-rot later after 30 DAS.

\section{References}

Chet, I., Haldar, Y., Katan, J. and Henis, Y., 1979. Biological control of soil borne plant pathogens by Trichoderma harzianum. Academic Press, New York, 581-591.

Devi, C.M. and reddy, M.N. 2002. In vitro screening of effective biocontrol agents against Rhizoctonia solani. J. Mycol. Plant Pathol., 32(3): 399.

Durral, L.W. 1968. Hyphal invasion by Trichoderma viride Mycopath. Mycol. Appl., 35: 138- 144.

Durwan, S. 1999. Evaluation of Trichoderma spp. as antagonist of Rhizoctonia solani. Revista Argentina-de-Microbiologia, 11(1): 13-18.

Elad, Y., Chet, I. and Henis, Y., 1982. Degradation of plant pathogenic fungi by Trichoderma harzianum, Can. J. Microbiol., 28: 719-725.

Elad, Y., Chet, I. and Katan, J. 1980. Trichoderma harzianum biocontrol agent effective against Sclerotium rolfsii and Rhizoctonia solani. Phyto-Pathol., 70: 119-121.
Harman, G.E., Chet, I. and Baker, R. 1981. Trichoderma hamatum effects on seed and seedling disease induced in radish and pea by Pythium spp. of Rhizoctonia solani. Phytopathol., 70: 1167-1172.

Indian Horticulture Database. 2011. National Horticulture Board.

Jash, S. and Pan, S. 2004. Stable mutants of Trichoderma virens for biological control of Rhizoctonia solani that causes seedling blight in green gram. $J$. Mycol. Plant Pathol., 34(2): 476-478.

Jatav, R.S. and Mathur, K., 2002. Biocontrol and integrated management of guar root rot incited by Rhizoctonia solani and Fusarium solani. J. Mycol. Plant Pathol., 32(3): 398.

Kim, H.K. and Roh, M.J. 1987. Isolation, identification and evaluation of biocontrol potential of rhizosphere and antagonistic to Rhizoctonia solani. $J$. Plant Pathol., 26: 87.

Manoranjitham, S.K., Prakasam, V., Rajappan, K. and Amutha, G. 2000. Control of chilli damping-off using bioagents. J. Mycol. Plant Pathol., 30(2): 225-228.

Marton, D.T. and Stroybeg, N.H. 1955. Antagonistic and stimulatory effect of micro-organism upon Sclerotium rolfsii. Phytopathol., 45: 419- 420.

Mathur, K. and Gurjar, R.B.S. 2002. Evaluation of different fungal antagonists plant extracts and oil cakes against Rhizoctonia solani causing stem rot of chilli. Annals of plant protection Sci., 10(2): 319- 322.

Melo. 2000. Parasitism of Rhizoctonia solani by strains of Trichoderma spp. Scientia Agricolo, 57(1): 55-59.

Rao, K.S., Krishna Murthy, K.V.M. and Prabhakar, V.M. 2000. Effect of rhizosphere fungi on pre-emergence damping-off disease of chilli seedling by soil application. Andhra Agri. J., 42(3-4): 241-244. 
Rifai, M.A. 1969. A revision of the genus Trichoderma. Mycol. Pap., 116: 1- 56

Saxena, D.R. and Saxena, M. 2002. Application of Trichoderma spp. for the management of soil borne pathogens causing drying of chillies. J. Mycol. Plant Pathol.,, 32(2): 270- 271.

Sharma, M. and Gupta, S.K. 2003. Ecofriendly methods for the management of root-rot and web-blight (Rhizoctonia solani) of French bean. J. Mycol. Plant
Pathol., 33(3): 345- 361.

Sharma, R.L., Singh, B.P. and Thakur, M.P. 2003. Antagonistic effect of Trichoderma harazianum against Fusarium oxysporum f. sp. lini causing wilt of linseed. J. Mycol. Plant Pathol., 33(3): 411-414.

Wu-Ws. 1982. Seed treatment by applying Trichoderma spp. to increase the emergence of soybeans. Seed Sci. Technol., 10(3): 557-563.

\section{How to cite this article:}

Aniruddh Prasad Pandey, Sunil Zacharia and Nithin B. Patil. 2017. Comparative Efficacy of Different Methods of Application of Trichoderma harazianum Rifai. in the Management of Dry Root Rot of Chilli (Capsicum annum) Caused by Rhizoctonia solani (kuhn). Int.J.Curr.Microbiol.App.Sci. 6(3): 482-489. doi: https://doi.org/10.20546/ijcmas.2017.603.056 